\title{
Design e sociedade: o papel social e o social elitizado
}

\author{
Autora: FERNANDES, Ivana; Graduanda em Design Gráfico (Universidade Federal de Pelotas) \\ Ivanafernandes.13@gmail.com
}

Co-autora: LESCHKO, Nadia Miranda; Doutora em Design (PUC-Rio, 2016), mestre em Memória Social e Patrimônio Cultural (UFPel, 2011) e graduada em Artes Visuais Habilitação Design Gráfico (UFPel, 2002). nadia.ufpel@gmail.com

Orientadora: WEYMAR, Lúcia Bergamaschi Costa; Doutora em Comunicação Social (PUCRS, 2010), mestre em Educação (UFPel, 2000) e graduada em Educação Artística (FURG, 1989).

luciaweymar@gmail.com

Palavras-Chave: Design social, profissão seletiva, papel social, elitização.

Resumo:

O presente artigo tem por objetivo discutir o papel social do designer gráfico buscando compreender o modo como impacta na sociedade atual assim como os motivos pelos quais a profissão torna-se por vezes seletiva e/ou elitizada, propondo uma reflexão bem como a mudança no modo como os profissionais atuam. Utilizando como base a revisão bibliográfica e subidivindo-a em duas partes, sendo a primeira de análise e a segunda de reflexão, foram trazidos autores que tratam do papel social do designer, dentre eles Joaquim Redig e Helen Armstrong, por exemplo. A grande contribuição para os profissionais é entender que, de fato, a profissão modifica e constroi a sociedade, de modo a interferir diretamente na vida daqueles que com ela tem contato. Trazer à tona temas como a elitização dos produtos propõe reflexões e grandes explanações sobre o tema, de modo a convidar os designers a uma mudança de atitude.

\section{Introdução}


Muitos são os textos, falas e conceitos que abordam as funções sociais do designer gráfico. Isto se dá pelo fato de que entender tudo que tangencia a profissão, desde a concepção dos produtos, o público alvo e o modo como as peças impactam e podem modificar a realidade social da audiência, auxilia na maneira pela qual o profissional se posiciona perante a comunidade. Tendo em vista tais fatores, o seguinte artigo busca compreender o papel social do designer gráfico na atual sociedade, assim como os impactos que este possui na vida dos indivíduos. Deste modo, serão abordados alguns autores que dissertam sobre Design Gráfico, seu papel social, de que modo a profissão pode ser elitizada ou seletiva e a invisibilidade do Design/designer dentro da sociedade.

\section{Metodologia}

Para a construção do artigo é realizada uma revisão bibliográfica, de duas fases. A primeira pretende compreender qual o papel social do designer gráfico, utilizando como principais autores Joaquim Redig. Marcos da Costa Braga, Helen Armstrong e Adélia Borges, a partir da união de algumas definições assim como o levantamento de reflexões sobre o tema. Estes são escolhidos principalmente pelo modo como abordam o papel social do profissional, de maneira a não apenas questionar, mas comprovar que, de fato, a profissão possui uma grande responsabilidade perante a sociedade.

A segunda fase, realizada a partir da fundamentação teórica realizada anteriormente, é voltada à reflexão do modo como a profissão torna-se elitizada determinadas vezes. Utilizando os mesmos autores da etapa anterior, a intenção é a de propor uma mudança no modo de atuação dos profissionais.

\section{Resultados e discussão}

\section{Design Social: redundância?}

Progressivamente o Design tem ganhado força e espaço na sociedade. Por conseguinte, compreender o modo de atuação assim como refletir sobre o do papel social do designer faz-se necessário.

Segundo Joaquim Redig (2011, p. 92),

[...] não existe design que não seja social- para a sociedade. Se não for, não é design. O que seria design não social? Design comercial? Design comercial que não for dirigido às necessidades da sociedade não é design.

Ao observar a elucidação do autor é possível levantar alguns questionamentos importantes: Qual o papel social do designer? Afinal, Design Social é uma redundância?

Como cita Marcos da C. Braga (2011), por ser criado a partir de um contexto, seja ele social, político, ou econômico o design não é capaz de ser imparcial. Deste modo, o designer sempre atende a alguma deficiência ou necessidade dentro de uma comunidade, servindo como ferramenta de construção e modificação da mesma. E é justamente esse seu papel social. O profissional da área tem a função de considerar não só a adaptação nos modos de produção, mas também a maneira como as peças atendem às necessidades do homem e a estética em que se encontra, por exemplo. "Seu trabalho consiste em ima- 
ginar, criar e encontrar meios de construir novos objetos que sirvam ao ser humano"(BORGES, 2003 p. 16).

O "ser social" da profissão já está implícito na própria atividade. Desde o início do projeto, no qual o designer inicia o processo com a definição de público alvo, metas e modo de projetação, a responsabilidade perante a audiência já está contida. A grande problematização está na contradição do discurso com a prática.

Armstrong (2015) cita o modo como os profissionais da área permanecem no anonimato na maioria das vezes. Posto isto, pode-se compreender um pouco mais dos motivos desta antítese entre o discurso proferido pelos profissionais e o seus atos. Essa ocultação da autoria do designer acarreta em uma criação de subcultura própria e, talvez por estar inundado pelos hábitos oriundos dessa cultura compartilhada apenas entre profissionais, pode não atender a todas as necessidades da audiência, por apenas perceber o conhecimento dos designers, e não o conhecimento, costumes e hábitos do público alvo a qual pretende atingir. Isto explica o fato da contradição do discurso com a prática.

Sendo assim, apesar da redundância do termo "Design Social", ou "Responsabilidade social com o Design", ou ainda "Papel social do designer" a profissão se eleva a um patamar místico pelo desconhecimento da população. "Embora visível por toda parte, o design ao mesmo tempo permanece invisível sem ser notado ou reconhecido." (ARMSTRONG, 2015 p. 6).

Essas definições podem muitas vezes acarretar em uma compreensão do Design como atributo empregado para construções de ambientes, objetos, e produções gráficas que possuem alto valor simbólico ou de estilo. Tantos adjetivos, erroneamente empregados, idealizam uma profissão onde a construção dos materiais oscila entre o mero ato de desenhar, o visual "clean" ou inovador, a característica empregada para elevar financeiramente a valia dos produtos ou, ainda, como artigos de luxo para cidadãos com maior poder aquisitivo (BORGES, 2003) (REDIG, 2011).

Segundo Helen Armstrong (2015, p.6) "Design é uma atividade social.". Observando a afirmação da autora, assim como os conceitos atribuídos à atividade e analisados no parágrafo anterior, é compreendido que o Design é uma ferramenta de modificação e construção da sociedade. Disseminar a prática, assim como os produtos oriundos da profissão, implica diretamente no papel social do designer. Estas verificações demonstram que o campo e o modo de atuação elevam o ofício para além da futilidade na qual é comumente associada.

\section{O social seletivo: um erro comum}

A partir das explanações e conceituações anteriores é possivel dar enfoque em mais um ponto da reflexão: o modo como o Design se torna elitizado e/ou seletivo.

Retomando o exemplo citado no tópico anterior no qual se discorre que, por vezes, o Design torna-se parte da construção de artigos de luxo para camadas mais elevadas da sociedade, é possível traçar uma

\section{UFPEL}


explanação. Adélia Borges (2003) expõe que, além de todo papel e responsabilidade social que possui, o design ainda auxilia na diferenciação de produtos em uma sociedade cada vez mais industrializada, cujo contato é com inúmeras outras peças e serviços. Para isso, cita que a profissão, "[...] está simultaneamente ligada à tecnologia, à estética e ao marketing." (BORGES, 2003 p.17). Isto auxilia na explicação dos motivos pelos quais muitas vezes estes artefatos se elevam a artigos de luxo. Tantas camadas na concepção de um produto tornam sua valia cada vez maior e, em consequência, tornam-se um design de luxo.

Retomando as ideias de Redig (2011) e Armstrong (2015), assim como o discurso sobre Design e responsabilidade social, deve-se ressaltar que não devemos relegar o Design somente às camadas mais abastadas da sociedade. Para a construção de uma profissão que não se torne mística no sentido de disseminação entre camadas sociais, a propagação dos produtos, assim como o reconhecimento dos mesmos e de quem os produzem, é importante em âmbito populacional. Compreender os problemas e encontrar soluções para a sociedade é papel fundamental do designer.

\section{Conclusão}

Através do artigo é possível uma melhor compreensão sobre o papel social do designer, sobre a formulação de teorias e críticas que possam enriquecer o modo como a profissão é vista em âmbito social. $A$ grande contribuição para a área, acreditam estas autoras, se dá pelo fato de que as reflexões assim como a percepção do Design como ferramenta de construção e modificação da sociedade, impactam diretamente no modo de produção dos designers de forma a evoluir e ter em consideração cada vez maior a audiência.

Refletir sobre elitização e mistificação da profissão tendo em vista o papel social do designer propõe questionamentos no modo de produção, fazendo o profissional modificar o comportamento perante ao público, modificando, consequentemente, a realidade que o ofício se encontra atualmente.

\section{Referências}

ARMSTRONG, Helen (org.). "Teoria do design gráfico". Tradução: Claudio Alves Marcondes. São Paulo: Cosac Naify, 2015. 208 p. Texto: "Prefácio", pg. 5 a 7.

BORGES, Adélia. "Designer não é personal trainer: e outros escritos". 2. ed. São Paulo: Rosari, 2003. 180 p. (Coleção Textos Design). Texto: "Desginer não é personal trainer", pg. 15 a 18.

BRAGA, Marcos da Costa (Org.). "O papel social do design gráfico: história, conceitos \& atuação profissional". São Paulo: SENAC São Paulo, 2011. 183 p. Texto: REDIG, Joaquim. "Design: responsabilidade social no horário do expediente", pg. 87 a 113. 